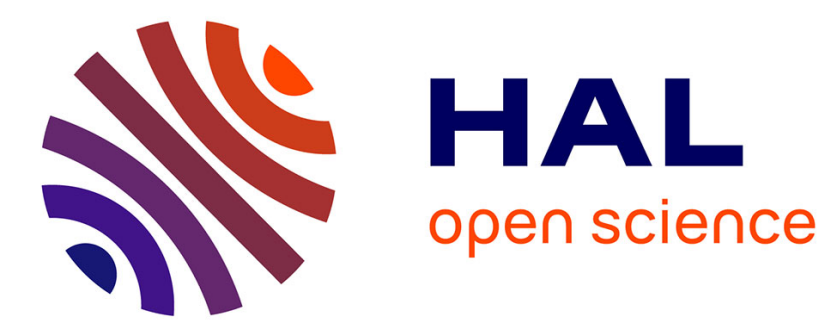

\title{
Temporal Dynamics of Active Prokaryotic Nitrifiers and Archaeal Communities from River to Sea
}

Mylène Hugoni, Hélène Agogué, Najwa Taib, Isabelle Domaizon, Anne Moné, Pierre E. Galand, Gisèle Bronner, Didier Debroas, Isabelle Mary

\section{- To cite this version:}

Mylène Hugoni, Hélène Agogué, Najwa Taib, Isabelle Domaizon, Anne Moné, et al.. Temporal Dynamics of Active Prokaryotic Nitrifiers and Archaeal Communities from River to Sea. Aquatic Microbial Ecology, 2015, 70 (2), pp.473-483. 10.1007/s00248-015-0601-z . hal-01354835

\author{
HAL Id: hal-01354835 \\ https://hal.science/hal-01354835
}

Submitted on 22 Aug 2016

HAL is a multi-disciplinary open access archive for the deposit and dissemination of scientific research documents, whether they are published or not. The documents may come from teaching and research institutions in France or abroad, or from public or private research centers.
L'archive ouverte pluridisciplinaire HAL, est destinée au dépôt et à la diffusion de documents scientifiques de niveau recherche, publiés ou non, émanant des établissements d'enseignement et de recherche français ou étrangers, des laboratoires publics ou privés. 


\section{Temporal dynamics of active prokaryotic nitrifiers and archaeal}

\section{communities from river to sea}

Mylène Hugoni ${ }^{1,2}$, Hélène Agogué ${ }^{3}$, Najwa Taib ${ }^{1,2}$, Isabelle Domaizon ${ }^{4}$, Anne Moné $^{1,2}$, Pierre

5 E. Galand ${ }^{5}$, Gisèle Bronner ${ }^{1,2}$, Didier Debroas ${ }^{1,2}$, Isabelle Mary ${ }^{1,2}$

(1) Clermont Université, Université Blaise Pascal, Laboratoire "Microorganismes : Génome et Environnement", BP 10448, F-63000 CLERMONT-FERRAND, France;

(2) CNRS, UMR 6023, LMGE, F-63171 AUBIERE, France;

10

(3) Littoral, Environnement et Sociétés (LIENs), UMR 7266, CNRS, University of La Rochelle, F-17000 La Rochelle, France;

(4) Institut National de la Recherche Agronomique, UMR 42 Centre Alpin de Recherche sur les Réseaux Trophiques et Ecosystèmes Limniques, F-74200 Thonon les Bains, France;

(5) Sorbonne Universités, UPMC Univ Paris 06, CNRS, Laboratoire d'Ecogéochimie des 15 Environnements Benthiques (LECOB), Observatoire Océanologique, 66650, Banyuls sur Mer, France.

Correspondance: Isabelle Mary, LMGE, Laboratoire Microorganismes: Génome et Environnement, UMR CNRS 6023, University Blaise Pascal (Clermont-Ferrand II), 24 avenue des Landais, BP 80026, Aubière 63171, France. Tel.: + 334734074 70; fax: + 334 734076 70; e-mail: isabelle.mary@univ-bpclermont.fr 


\section{Abstract}

To test if different niches for potential nitrifiers exist in estuarine systems, we assessed by pyrosequencing the diversity of archaeal gene transcript markers for taxonomy (16S rRNA) during an entire year along a salinity gradient in surface waters of the Charente estuary (Atlantic coast, France). We further investigated the potential for estuarine prokaryotes to oxidize ammonia and hydrolyze urea by quantifying thaumarchaeal $a m o A$ and $u r e C$, and bacterial amoA transcripts. Our results showed a succession of different nitrifiers from river to sea with bacterial amoA transcripts dominating in the freshwater station while archaeal transcripts were predominant in the marine station. The $16 \mathrm{~S}$ rRNA sequence analysis revealed that Thaumarchaeota Marine Group I (MGI) were the most abundant overall but other archaeal groups like Methanosaeta were also potentially active in winter (December-March) and Euryarchaeota Marine Group II (MGII) were dominant in seawater in summer (AprilAugust). Each station also contained different Thaumarchaeota MGI phylogenetic clusters, and the clusters' microdiversity was associated to specific environmental conditions suggesting the presence of ecotypes adapted to distinct ecological niches. The amoA and ureC transcript dynamics further indicated that some of the Thaumarchaeota MGI subclusters were involved in ammonia oxidation through the hydrolysis of urea. Our findings show that ammonia oxidizing Archaea and Bacteria were adapted to contrasted conditions and that the Thaumarchaeota MGI diversity probably corresponds to distinct metabolisms or life strategies.

Keywords: Ammonia oxidation / amoA / Archaea / gradient / diversity 
During the last decades, studies on microbial ecology have provided compelling evidence of the ubiquity and abundance of Archaea in a wide variety of aquatic habitats [1,2]. Further, the discovery of genes encoding enzymes related to nitrification in archaeal metagenomes from soil and marine waters [3-5] and the isolation of the first autotrophic archaeal nitrifier, Nitrosopumilus maritimus [6] have led to a dramatic shift in the classical view that Bacteria were the main responsible for nitrification.

The wide distribution of ammonia oxidizing Archaea (AOA), affiliated with Thaumarchaeota, across a variety of aquatic environments is now well established through reports on the abundance of the gene encoding archaeal ammonia monooxygenase $\alpha$-subunit $(a m o A)$ in oceanic waters $[7,8]$ and freshwater ecosystems $[9,10]$. Nevertheless, the relative contribution of AOA versus ammonia oxidizing Bacteria (AOB) remains unclear and factors that regulate ammonia oxidizing microorganisms' activity and diversity in aquatic ecosystems have not yet been fully elucidated. While in marine ecosystems AOA often outnumber AOB [8,11], the ecology of nitrifiers appears more complex along salinity gradients. Indeed, some studies reported that AOB dominate under saline estuarine conditions [12-14], while others showed that AOA always dominate in estuarine systems [15]. In lakes, contrasting results have been reported as AOB were absent from an oligotrophic high-altitude lake [16] but were predominant in nutrient-rich compared to oligotrophic waters [9]. Additionally the discovery that some Thaumarchaeota may degrade urea to use nitrogen for their metabolism $[17,18]$, and the absence of the $u r e C$ gene (encoding the alpha subunit of a putative archaeal urease) in the representative marine isolate, Nitrosopumilus maritimus [19], raises new questions about the existence of different archaeal nitrifier ecotypes able to cope with different environmental conditions or potential competitors $[17,18,20]$. However, little is known about their possible niche differentiation associated with their various metabolisms [17,21] and their ability to 
assimilate inorganic carbon [22]. In particular, their potential activity in relation to seasonal changes, salinity and chemical gradients, remains poorly understood.

Microbial communities in estuaries and some coastal margins vary greatly in space and time because of sharp gradients in salinity and nutrients $[23,24]$. The mixing of fresh- and saltwater creates steep physico-chemical gradients that are coupled to shifts in the resident microbial communities, and particularly ammonia oxidizers [15]. Community transitions from marine to freshwater are explained by salinity, which is the main factor driving community structure globally $[25,26]$. Temperature, nitrite and ammonia concentrations, and net primary productivity have, however, also been shown to produce major effects on the nitrifiers community structure. Transitions between bacterial and archaeal ammonia oxidizers communities have been frequently detected $[13,27,28]$.

Estuarine Archaea usually originate from both marine and freshwater environments but also from soils and sediments [15,29]. In riverine ecosystems, Euryarchaeota and Thaumarchaeota are both present but their proportion can vary according to the studied location. Indeed, Thaumarchaeota dominated in the Rhine river, while Euryarchaeota were

90 the most abundant in the arctic Mackenzie river [30,31]. Even though the diversity of riverine Archaea starts to be described, their ecology and seasonal dynamics remain poorly understood because of the lack of temporal surveys. In addition, the potential activity (at the $16 \mathrm{~S}$ rRNA level) of riverine archaeal communities is not known as aquatic microorganisms have traditionally been studied at the DNA level $[32,33]$. However, the recent use of both $16 \mathrm{~S}$ rRNA genes and 16S rRNA has shown the importance of differentiating the potentially active communities from the total communities for a better understanding of the ecology of aquatic microorganisms $[34,35]$.

Here we studied an estuary to test at a domain level whether Bacteria and Archaea had different niches for nitrification. We then looked more specifically at Archaea to test if 
different thaumarchaeal ecotypes had different habitats and metabolisms. We quantified thaumarchaeal amoA and $u r e C$ transcripts in comparison to bacterial amoA over one year along a salinity gradient in the surface water of the Charente Estuary (west coast of France), and we described the community structure of potentially active Archaea by pyrosequencing cDNA from the V3-V5 region of 16S rRNA gene.

105

\section{Materials and Methods}

\section{Study sites, sampling and chemical analyses}

The Charente is a $350 \mathrm{~km}$ coastal river draining a $10,000 \mathrm{~km}^{2}$ basin and emerging in the bay of Marennes Oleron. The sampling area (Figure 1) started at St-Savinien, upstream of the

110 Charente (freshwater station, $45^{\circ} 52^{\prime} 37^{\prime \prime} \mathrm{N}, 00^{\circ} 41^{\prime} 10^{\prime \prime} \mathrm{W}$ ) and ended in the Charente estuary (marine station, $45^{\circ} 59^{\prime} 54^{\prime \prime}, 01^{\circ} 09^{\prime} 56^{\prime \prime} \mathrm{W}$ ), with one intermediary station (mesohaline station, $\left.45^{\circ} 58^{\prime} 11^{\prime \prime} \mathrm{N}, 01^{\circ} 00^{\prime} 50^{\prime \prime} \mathrm{W}\right)$. Each station was characterized by a specific salinity class ranging from 0 to 35 PSU (Supplementary Table 1$)$. Surface water $(0.5 \mathrm{~m}$ depth) was collected monthly in each station from April 2011 to March 2012, except May 2011 in the marine 115 station, by using a 10-L Niskin Bottle. Water temperature, salinity and $\mathrm{pH}$ were determined with a multiparameter probe (YSI GRANT 3800). Phosphate $\left(\mathrm{PO}_{4}{ }^{3-}\right)$ and ammonia $\left(\mathrm{NH}_{4}{ }^{+}\right)$ contents were analyzed using Merck colorimetric kits (Millipore) according to standard American Public Health Association (1992) methods. Chlorophyll $a$ (Chla) concentration was determined by spectrophotometry [36,37].

\section{RNA extraction and pyrosequencing}

A sub-sample $(300 \mathrm{~mL}$ ) added with an equal volume of RNA Later (ammonia sulfate $7.93 \mathrm{M}$, sodium citrate $0.025 \mathrm{M}$, EDTA $0.02 \mathrm{M}, \mathrm{pH}$ 5.2) was pre-filtered through 5- $\mu \mathrm{m}$ pore-size polycarbonate filters (Millipore) and collected on $0.2-\mu \mathrm{m}$ pore-size (pressure $<10 \mathrm{kPa}$ ) 
125 polycarbonate filters (Millipore) and stored at $-80^{\circ} \mathrm{C}$ until nucleic acid extraction. The RNA extraction method was modified from Hugoni et al. [35] using a combination of mechanic and enzymatic cell lysis, followed by extraction using the AllPrep DNA/RNA kit (Qiagen, Valencia, CA). The RNA samples were tested for the presence of contaminating genomic DNA by PCR and then reverse transcribed with random primers using the SuperScript ${ }^{\circledR}$ VILO

130 (Invitrogen). The amplification of the V3-V5 region of the 16S rRNA genes was performed with universal archaeal primers Arch349F and Arch806R (Table 1, [38]), followed by pyrosequencing using a Roche 454 GS-FLX system with titanium chemistry by a commercial laboratory (MR.DNA, Shallowater, TX, USA).

\section{Bioinformatic analysis}

The 16S rRNA pyrosequencing dataset represented 175,637 raw sequences. Cleaning procedures consisted in the elimination of sequences presenting ambiguous bases " $\mathrm{N}$ ", a quality score $<25$, length less than $200 \mathrm{bp}$ and with a mismatch in the forward primer. The remaining reads were clustered at $97 \%$ similarity threshold [39] and representative sequence

140 for each OTU were inserted in phylogenetic trees for taxonomic annotation. The process was automated by PANAM that also computed richness and diversity indexes, Chao1 and Shannon respectively (http://code.google.com/p/panam-phylogenetic-annotation/ downloads/list; [40]). Chimeras were detected using Uchime [41] and represented $1 \%$ of the cleaned sequences. After the removal of sequences affiliated with Bacteria, the dataset

145 contained a total of 27,803 archaeal sequences distributed into 1825 OTUs (Supplementary Table 1). Several sequences were affiliated with Bacteria belonging to the Verrucomicrobia phylum suggesting that the chosen Archaea primers were not as specific as thought, and that they may not have amplified all archaeal sequences in the estuary. For the analysis of the 
seasonal dynamics, the $16 \mathrm{~S}$ rRNA samples were randomly resampled down to 212 sequences using PANAM.

A phylogenetic tree including OTUs retrieved in the 3 sampling stations was constructed by aligning both OTUs and reference sequences from the literature using Muscle [42] and neighbor joining phylogenies were built using Mega5 [43] and a bootstrap iteration of 500. This allowed us to delineate major Thaumarchaeota MGI clusters and evaluate the

155 proportion of OTUs belonging to each cluster retrieved in each station.

\section{RT quantitative PCR analysis}

The qPCR protocol modified from Hugoni et al. [9] targeted the cDNA transcribed and included the primers described in the Table 1. Briefly, transcript numbers of thaumarchaeal amoA and ureC and bacterial amoA were determined in triplicate. The reaction mixture (25 $\mu \mathrm{L})$ contained MESA GREEN qPCR MasterMix Plus for SYBR Assay ${ }^{\circledR}$ (1X, Eurogentec) added with $0.8 \mu \mathrm{g}$ of BSA, $0.7 \mu \mathrm{M}$ of primers and ultra-pure sterile water. One $\mu \mathrm{L}$ of cDNA was added to $24 \mu \mathrm{L}$ of mix in each well. qPCR reactions consisted of an initial denaturing step at $94^{\circ} \mathrm{C}$ (for $15 \mathrm{~min}$ for thaumarchaeal amoA, and $5 \mathrm{~min}$ for thaumarchaeal ureC and

165 bacterial $a m o A$ transcripts) followed by 40 cycles (thaumarchaeal $a m o A: 94^{\circ} \mathrm{C} 15 \mathrm{sec}, 52^{\circ} \mathrm{C}$ $30 \mathrm{sec}, 72^{\circ} \mathrm{C} 30 \mathrm{sec}$; thaumarchaeal ureC: $94^{\circ} \mathrm{C} 1 \mathrm{~min}, 55^{\circ} \mathrm{C} 1 \mathrm{~min}, 72^{\circ} \mathrm{C} 2 \mathrm{~min}$ and bacterial amoA: $\left.95^{\circ} \mathrm{C} 30 \mathrm{sec}, 56^{\circ} \mathrm{C} 40 \mathrm{sec}, 72^{\circ} \mathrm{C} 2 \mathrm{~min}\right)$. Standard curves were generated from a mix of clone representatives from the environments studied (sequences were obtained using the Arch AmoR and Arch AmoF primers [44] and have been archived in GenBank under accession numbers: KF432403 and KF432404 for the thaumarchaeal ureC gene, JN089917 and JN089905 for the archaeal amoA gene, JX003650 and JX003657 for the bacterial amoA gene). All reactions were performed with standard curves spanning from $10^{1}$ to $10^{8}$ copies per $\mu \mathrm{L}$. Mean PCR efficiencies and correlation coefficients for standard curves were as follows: 
for the thaumarchaeal ureC assay, $98 \%, \mathrm{r}^{2}=0.98$, for the thaumarchaeal amoA assay, $108 \%$, $175 \mathrm{r}^{2}=1.00$, and for the bacterial amoA assay, $107 \%, \mathrm{r}^{2}=1.00$.

\section{Statistical analysis}

Canonical correspondence analysis (CCA) was performed to assess the relationships between active archaeal taxonomic groups and environmental parameters. CCA was performed on 6

180 environmental factors (temperature, salinity, Chl $a$ content, $\mathrm{pH}$, phosphate, and ammonium concentrations) and the taxonomic groups abundance matrix (inferred from 16S rRNA reads number).

To explain the variation of archaeal amoA and ureC transcripts abundance, a redundancy analysis (RDA) was used after a forward selection [45] of the 10 thaumarchaeal

185 OTUs susceptible to explain a significant part of changes in archaeal amoA and ureC transcripts abundance (inferred from the qPCR assays).

The statistical analyses were conducted using $\mathrm{R}$ associated to the package VEGAN (http://cran.r-project.org/web/packages/vegan/index.html).

\section{Results}

\section{Environmental characteristics of the Charente estuary}

Three stations of the Charente estuary (Figure 1) were sampled monthly during one year along a salinity gradient (Supplementary Table 1). The freshwater, mesohaline and marine stations were characterized by a mean salinity of $0,14.9$ and 33.2 PSU and a mean Chla concentration of 17.6, 4.34 and $2.74 \mu \mathrm{g} \mathrm{L}^{-1}$, respectively (Supplementary Table 1). Ammonia concentrations were on average lower in the marine station $\left(0.019 \mathrm{mg} \mathrm{L}^{-1}, \mathrm{SD}=0.034\right)$ than in the freshwater station $\left(0.081 \mathrm{mg} \mathrm{L}^{-1}, \mathrm{SD}=0.035\right)$. Conversely phosphate concentrations were 
higher in the marine station $\left(0.096 \mathrm{mg} \mathrm{L}^{-1}, \mathrm{SD}=0.056\right)$ than in the freshwater station $(0.038$ $\left.\mathrm{mg} \mathrm{L}^{-1}, \mathrm{SD}=0.034\right)$.

200

\section{Bacterial and archaeal amoA and archaeal ureC transcript dynamics}

Archaeal and bacterial amoA transcript numbers were quantified by RT-qPCR during one year (Figure 2.A and B). Few archaeal $a m o A$ transcripts were detected overall in the freshwater station. Nevertheless, three distinct periods of higher transcript numbers were observed: one from May to June, then a second during September and October and finally from December to January (Figure 2.A). The mesohaline station was characterized by higher archaeal amoA transcript numbers from May to September with a peak in June. Conversely, the marine archaeal $a m o A$ transcript numbers showed an increase in abundance from October to January, with a peak in January.

In the freshwater station, bacterial amoA transcript numbers increased first in June and then peaked in September, reaching up to 225 times more transcripts than Archaea at the same period (Figure 2.B). In the mesohaline station, bacterial amoA transcripts showed similar dynamics to that of Archaea with three peaks, although their magnitude was overall lower. The marine station had the lowest number of bacterial amoA transcripts, with an increase from August to October, earlier in the year compared to archaeal amoA.

Thaumarchaeal ureC transcript abundance was also determined using RT-qPCR during a one-year period to assess the genetic potential of estuarine Archaea for ureolytic nitrogen metabolism (Figure 2.C). Transcript numbers were overall very low but were still within the detection range according to our standard curve. The freshwater station presented the highest transcripts abundance that corresponded precisely to the periods of highest archaeal amoA abundance in this station. In both the mesohaline and marine stations, lower 
numbers of ureC transcripts were detected all year, except in May and June at the mesohaline station when numbers were slightly higher.

\section{Active Archaea community structure and dynamics}

The changes in the community structure of active archaeal populations were evaluated over time from river to sea by pyrosequencing cDNA from the $16 \mathrm{~S}$ rRNA gene (Supplementary Table 1). The community diversity was evaluated through the Shannon index on normalized datasets, and was significantly higher in the freshwater than in the marine station (t-test, $\mathrm{p}$

$230=0.008$, Supplementary Figure 1). Moreover, the number of OTUs was also different between stations with 550 OTUs observed in the freshwater station against 923 and 352 in the mesohaline and marine stations respectively. We did not manage to amplify archaeal cDNA from October to November at the marine station.

We evaluated active archaeal community composition, based on $16 \mathrm{~S}$ rRNA

235 transcripts, and focused on the three main periods of high archaeal amoA transcripts abundance. In the freshwater station, different patterns of community composition were visible with time (Figure 3). The $16 \mathrm{~S}$ rRNA Thaumarchaeota MGI sequences were more abundant from April to November representing about $83 \%$ of the archaeal sequences. These Thaumarchaeota were dominated by 11 different OTUs with best Blast match to sequences

240 recovered from lacustrine freshwaters, groundwater, rivers and mangrove sediments. In contrast, the number of sequences affiliated with methanogenic groups (i.e. Methanosaeta, Methanoregula, Methanoculleus, Methanomicrobiales, Methanospirillum) increased from December to March reaching up to $60 \%$ of the sequences. Five methanogen OTUs all belonging to the Methanosaeta genus dominated. They were closely related to sequences

245 found in salt marsh and lacustrine sediments, but also retrieved in groundwater and wetlands. 
Among Euryarchaeota we detected few members of the Rice Cluster-V (RC-V) and Deep-sea Hydrothermal Vent Euryarchaeotic Group - 6 (DHVEG-6).

In the mesohaline station, the potentially active archaeal community was clearly dominated by Thaumarchaeota MGI all year round (from $86 \%$ to $93 \%$ of the sequences, 250 Figure 3), but by different subgroups at different times (Figure 4). Within Euryarchaeota, few methanogenic lineages were retrieved in the mesohaline station and, Euryarchaeota MGII represented about $7 \%$ of the sequences between December and March.

In the marine station, we could also distinguish changes with seasons. From April to August, Thaumarchaeota MGI represented about $17 \%$ of the $16 \mathrm{~S}$ rRNA transcripts, the remaining being almost exclusively Euryarchaeota MGII sequences (around 81\%). Conversely, from December to March, Thaumarchaeota MGI represented about $70 \%$ of the sequences while Euryarchaeota MGII accounted for $27 \%$ of the sequences. Six abundant Thaumarchaeota OTUs were related to marine waters sequences but also to lacustrine freshwater, groundwater, rivers and mangrove sediment. On the other hand, the fifteen abundant Euryarchaeota OTUs were related to marine sequences.

The canonical correspondence analysis showed that Euryarchaeota MGII was mainly related to salinity and consequently to the marine station. On the other hand, the potentially active Thaumarchaeota MGI were linked to the mesohaline station, while the majority of euryarchaeal groups (i.e. methanogenic lineages, RC-V, Lake Dagow Sediment cluster (LDS), Miscellaneous Euryarchaeotic Group (MEG), Miscellaneous Crenarchaeotic Group (MCG)) were related to ammonia and to the freshwater station (Supplementary Figure 2).

We used all Thaumarchaeota MGI OTUs retrieved in all the stations to build a phylogenetic tree. The potentially active OTUs fell into six major subclusters (Figure 4). Among them, the clusters Marine A and B were initially recovered in marine ecosystems $270[35,46]$ and the clusters Freshwater $\mathrm{A}$ and $\mathrm{B}$, in freshwaters [9,44]. Interestingly, we also 
found OTUs belonging to a subcluster related to sediments. OTUs present in the freshwater station belonged mainly to the Freshwater A and Sediment associated groups, while those in the mesohaline and the marine stations clustered mainly with sequences belonging to the Marine A subcluster. OTUs common to both the freshwater and the mesohaline stations fell into the Sediment subcluster while those that were specific of the mesohaline and marine station mostly fell into the Marine A subcluster.

We further analyzed Thaumarchaeota MGI OTUs present in the mesohaline station and identified 3 monophyletic subclusters within the Thaumarchaeota MGI_Marine A cluster (Figure 4). Each of these subclusters had a specific seasonal dynamics (Supplementary Table 2 and 3). The first subcluster named MGI.A.b was potentially active from April to August, the second named MGI.A.a from September to November and the last one called MGI.A.c from December to March (Figure 4).

To gain insight into possible associations between 16S rRNA OTUs and functional genes, we used a forward redundancy analysis (RDA) of amoA and ureC transcript abundances against the most abundant thaumarchaeal OTUs retrieved in all sampling stations (Figure 5). The ten most informative OTUs (i.e. accounting for $77 \%$ of the total variation) were selected to build a RDA. It showed that the potential ureolytic metabolism was correlated to three OTUs (R16_HUJB0N002GU20W, R24_HUJB0N002JCR91 and R10_HUJB0N002JLORV), affiliated with the Sediment and Freshwater A subclusters (Figure 4). On the other hand, the $a m o A$ potential activity was correlated with six OTUs among which five were affiliated with the Marine A subcluster while the last one was affiliated with the Freshwater B subcluster.

\section{Discussion}


295 The quantification of amoA transcript abundance in the surface waters of the Charente estuary over a 1-year period showed a transition in active ammonia-oxidizing populations from AOB in freshwaters to $\mathrm{AOA}$ in marine waters. The higher $\mathrm{AOB}$ transcript numbers in the freshwater station is in agreement with previous studies suggesting that AOB potential nitrification rates were inhibited in high salinity environment (around 30 PSU [27]). 300 Nevertheless, even if salinity appears to be an important factor in determining AOB distribution, Bernhard et al. [27] showed that AOB exhibited a broad range of salinity tolerance, suggesting that other environmental parameters needed to be considered to understand their activity dynamics. In contrast, AOA potential activity was very low in freshwater, while intermediary estuarine conditions (mesohaline station) favored higher 305 transcript abundance through the whole year. In contrast, previous studies based on DNA, have shown that archaeal amoA genes were more abundant in freshwater $[13,14,47]$. However, these studies and our data showed that the highest thaumarchaeal transcript abundance was retrieved when ammonia concentrations were the lowest, probably because of the high apparent affinity of Thaumarchaeota for reduced nitrogen [48]. In the marine station, 310 thaumarchaeal amoA transcript numbers were more important during the winter period, consistent with previous results showing highest archaeal amoA gene abundance in winter in the Mediterranean Sea [7]. Winter may be a period during which Thaumarchaeota MGI are more active and win the competition for ammonia against Bacteria [49]. In our study, AOA activity evaluated through $16 \mathrm{~S}$ rRNA could not be statistically linked to any of the

315 environmental parameters measured, suggesting that other factors (i.e. other physico-chemical parameters or bottom up controls) shape AOA activity in this ecosystem.

We detected possible Thaumarchaeota MGI ecotypes presenting different seasonal dynamics and associated with varying levels of potential ammonia oxidation activity. In particular, the changes observed among Marine A subclusters suggest that the phylogenetic 
diversity was associated with contrasted seasonal conditions. The variable potential activity levels of the different Thaumarchaeota MGI subclusters could suggest an adaptation to different niches and may indicate an ecological specialization, supporting the notion that different Thaumarchaeota MGI could have different metabolisms [21]. Although we could not precisely define ecological niches in the present study, our work confirms the idea that 325 Thaumarchaeota MGI is composed of different ecotypes, as previously proposed for the coastal Mediterranean Sea [35,50] and lakes [16,51,52]. The use of ureolysis to supply ammonia when AOB activity dominates is a possible example of the specific adaptations of some Thaumarchaeota MGI ecotypes to particular niches. This was illustrated in our study through the finding that the Thaumarchaeota ureC transcripts were detected in the freshwater 330 station, when AOB amoA transcripts outnumbered AOA. Thaumarchaeota MGI could use urea to fuel nitrification and thus adopt an alternative metabolic pathway when the availability of ammonia is limited and/or when competitors are present [18]. In our study, the presence of ureC transcripts was associated to the presence of specific Thaumarchaeota MGI OTUs affiliated with the Freshwater A and Sediment subclusters. Not all Thaumarchaeota MGI

335 OTUs might be able to use urea for nitrification, as illustrated by the weak ureC transcripts number found in the marine station despite the high abundance of Thaumarchaeota and as suggested by the absence of the ureC gene in the $N$. maritimus genome [19]. Thus we hypothesize that only some specific clusters have the ureolytic potential, and that this metabolism is preferentially present in Thaumarchaeota from freshwater systems. However, 340 caution is needed when interpreting such results as the detection of genes and transcripts does not warranty metabolic activities of Archaea. It was for instance recently suggested that Thaumarchaeota expressing amoA are not obligate ammonia oxidizers [53], and thus amoAcarrying Archaea are not necessarily ammonia oxidizers [54]. More work is needed to understand if and what AOA are involved in urea utilization and under which conditions. 
The occurence of active methanogenic groups in the freshwater station, particularly abundant during the winter months (December-March), may be due to the presence of sediments or mud mixed with the water during rainfalls and/or storms. Our results also suggest that the types of methanogens present may thrive better in freshwater environments rather than in marine and brackish environments. The retrieval of sequences affiliated with methanogens in the mesohaline station could suggest that they were slowly dispersed from their habitat (i.e. freshwater), resulting in decreasing activity with increasing salinity [55]. Some specific freshwater groups like LDS or RC-V clusters were also found (4.8 and $11.9 \%$ of the reads respectively), indicating discharge from nearby rivers and from the catchment area. The RC-V and LDS cluster represent highly diverse groups of Euryarchaeota detected 355 in various ecosystems [56]. They have been identified in rivers [30,31] where they represent a large proportion of the archaeal cell counts [31]. In the marine station, there was a clear succession between Thaumarchaeota MGI and Euryarchaeota MGII. The predominance of potentially active Thaumarchaeota MGI occurred during the winter period, as previously shown in the North-Western Mediterranean Sea [35]. Euryarchaeota MGII dominated the 360 active archaeal assemblage during the summer period. The putative presence of genes encoding the proteorhodopsin, retrieved in members of marine Euryarchaeota MGII.a [57,58] could explain the ecological success of this group in the marine station. Our study also confirms the potential activity of some less abundant groups, like Marine Benthic Group B (MBG-B) and the recently proposed "Bathyarchaeota" formerly known as Miscellaneous 365 Crenarchaeotic Group [59,60] retrieved in the freshwater and mesohaline stations. This suggests that these groups considered as ubiquitous [61] and usually found in sediments [62] could be active in estuarine water column. A recent study using a single-cell genome approach reported that some members of the MCG are capable of protein remineralization in 
anoxic sediments and it may be that these organisms are undertaking such a process in this

environment [63].

In summary, our study clearly showed that the potential activity of prokaryotic nitrifiers was influenced by the physico-chemical gradients retrieved through an estuarine ecosystem. At the domain level, Archaea and Bacteria occupied different ecological niches with $\mathrm{AOB}$ being more active in freshwater and $\mathrm{AOA}$ in marine waters. Our results also suggest the presence of different thaumarchaeal ecotypes, which maybe able to degrade urea adding to the growing evidence that additional metabolisms may be present within Thaumarchaeota.

\section{Acknowledgments}

380 We thank P. Pineau, N. Lachaussée, M. Breret, F. Mornet, L. Beaugeard, J. Lavaud and J. Jourde for the sampling. We thank A. Vellet, I. Louati, M. Breret and C. Lavergne for their technical support during the experimentations, J.C. Auguet for providing us the map of the sampling location of the stations. This work was supported by a CNRS Program Ecosphère Continentale et Côtière (EC2CO, 2010-2012). The work of PE Galand was supported by the Agence Nationale de la Recherche (ANR) project MICADO (ANR-11JSV7-003-01).

\section{References}

1. DeLong EF (1992) Archaea in coastal marine environments. Proc Natl Acad Sci USA 89: $5685-5689$.

390 2. Auguet JC, Casamayor EO (2008) A hotspot for cold crenarchaeota in the neuston of high mountain lakes. Environ Microbiol 10: 1080-1086.

3. Hallam SJ, Mincer TJ, Schleper C, Preston CM, Roberts K, et al. (2006) Pathways of carbon assimilation and ammonia oxidation suggested by environmental genomic analyses of marine Crenarchaeota. PLoS Biol 4: e95.

395 4. Treusch AH, Leininger S, Kletzin A, Schuster SC, Klenk HP, et al. (2005) Novel genes for nitrite reductase and Amo-related proteins indicate a role of uncultivated mesophilic crenarchaeota in nitrogen cycling. Environ Microbiol 7: 1985-1995. 
5. Venter JC, Remington K, Heidelberg JF, Halpern AL, Rusch D, et al. (2004) Environmental genome shotgun sequencing of the Sargasso Sea. Science 304: 66-74.

6. Konneke M, Bernhard AE, de la Torre JR, Walker CB, Waterbury JB, et al. (2005) Isolation of an autotrophic ammonia-oxidizing marine archaeon. Nature 437: 543-546.

7. Galand PE, Gutierrez-Provecho C, Massana R, Gasol J, Casamayor EO (2010) Inter-annual recurrence of archaeal assemblages in the coastal NW Mediterranean Sea. Limnol Oceanogr 55: 2117-2125.

8. Mincer TJ, Church MJ, Taylor LT, Preston C, Karl DM, et al. (2007) Quantitative distribution of presumptive archaeal and bacterial nitrifiers in Monterey Bay and the North Pacific Subtropical Gyre. Environ Microbiol 9: 1162-1175.

9. Hugoni M, Etien S, Bourges A, Lepere C, Domaizon I, et al. (2013) Dynamics of ammonia-oxidizing Archaea and Bacteria in contrasted freshwater ecosystems. Res $410 \quad$ Microbiol 164: 360-370.

10. Vissers EW, Anselmetti FS, Bodelier PL, Muyzer G, Schleper C, et al. (2013) Temporal and spatial coexistence of archaeal and bacterial amoA genes and gene transcripts in Lake Lucerne. Archaea 2013: 289478.

11. Beman JM, Popp BN, Francis CA (2008) Molecular and biogeochemical evidence for ammonia oxidation by marine Crenarchaeota in the Gulf of California. ISME J 2: 429-441.

12. Magalhães C, Machado A, Bordalo A (2009) Temporal variability in the abundance of ammonia oxidizing bacteria vs. archaea in sandy sediments of the Douro River estuary, Portugal. Aqua Microbial Ecol 56: 13-23.

420 13. Mosier AC, Francis CA (2008) Relative abundance and diversity of ammonia-oxidizing archaea and bacteria in the San Francisco Bay estuary. Environ Microbiol 10: 30023016.

14. Santoro AE, Francis CA, de Sieyes NR, Boehm AB (2008) Shifts in the relative abundance of ammonia-oxidizing bacteria and archaea across physicochemical gradients in a subterranean estuary. Environ Microbiol 10: 1068-1079.

15. Bernhard AE, Bollmann A (2010) Estuarine nitrifiers: New players, patterns and processes. Estuar, Coastal Shelf Sci 88: 1-11.

16. Auguet JC, Triado-Margarit X, Nomokonova N, Camarero L, Casamayor EO (2012) Vertical segregation and phylogenetic characterization of ammonia-oxidizing Archaea in a deep oligotrophic lake. ISME J 6: 1786-1797.

17. Qin W, Amin SA, Martens-Habbena W, Walker CB, Urakawa H, et al. (2014) Marine ammonia-oxidizing archaeal isolates display obligate mixotrophy and wide ecotypic variation. Proc Natl Acad Sci USA 111: 12504-12509.

18. Alonso-Saez L, Waller AS, Mende DR, Bakker K, Farnelid H, et al. (2012) Role for urea in nitrification by polar marine Archaea. Proc Natl Acad Sci USA 109: 17989-17994.

19. Walker CB, de la Torre JR, Klotz MG, Urakawa H, Pinel N, et al. (2010) Nitrosopumilus maritimus genome reveals unique mechanisms for nitrification and autotrophy in globally distributed marine crenarchaea. Proc Natl Acad Sci USA 107: 8818-8823.

20. Pedneault E, Galand PE, Potvin M, Tremblay JE, Lovejoy C (2014) Archaeal amoA and ureC genes and their transcriptional activity in the Arctic Ocean. Sci Rep 4: 4661.

21. Beam JP, Jay ZJ, Kozubal MA, Inskeep WP (2014) Niche specialization of novel Thaumarchaeota to oxic and hypoxic acidic geothermal springs of Yellowstone National Park. ISME J 8: 938-951.

22. Konneke M, Schubert DM, Brown PC, Hugler M, Standfest S, et al. (2014) Ammoniaoxidizing archaea use the most energy-efficient aerobic pathway for $\mathrm{CO} 2$ fixation. Proc Natl Acad Sci U S A 111: 8239-8244. 
23. Herlemann DP, Labrenz M, Jurgens K, Bertilsson S, Waniek JJ, et al. (2011) Transitions in bacterial communities along the $2000 \mathrm{~km}$ salinity gradient of the Baltic Sea. ISME J 5: 1571-1579.

24. Kirchman DL, Dittel AI, Malmstrom RR, Cottrell MT (2005) Biogeography of major bacterial groups in the Delaware Estuary. Limnol Oceanogr 50: 1697-1706.

25. Lozupone CA, Knight R (2007) Global patterns in bacterial diversity. Proc Natl Acad Sci USA 104: 11436-11440.

26. Auguet JC, Barberan A, Casamayor EO (2009) Global ecological patterns in uncultured Archaea. ISME J 4: 182-190.

27. Bernhard AE, Tucker J, Giblin AE, Stahl DA (2007) Functionally distinct communities of ammonia-oxidizing bacteria along an estuarine salinity gradient. Environ Microbiol 9: 1439-1447.

28. Santoro AE, Casciotti K, Francis CA (2010) Activity, abundance and diversity of nitrifying archaea and bacteria in the central California Current. Environ Microbiol Reports 12: 1989-2006.

29. Galand PE, Lovejoy C, Pouliot J (2008) Microbial community diversity and heterotrophic production in a coastal Arctic ecosystem: A stamukhi lake and its source waters. Limnol Oceanogr 53: 813-823.

30. Galand PE, Lovejoy C, Vincent WF (2006) Remarkably diverse and contrasting archaeal communities in a large arctic river and the coastal Arctic Ocean. Aquat Microb Ecol 44: 115-126.

31. Herfort L, Kim JH, Coolen MJL, Abbas B, Schouten S, et al. (2009) Diversity of Archaea and detection of crenarchaeotal $a m o A$ genes in the river Rhine and Têt. Aquat Microb

$470 \quad$ Ecol 55: 189-201.

32. Alonso-Saez L, Balague V, Sa EL, Sanchez O, Gonzalez JM, et al. (2007) Seasonality in bacterial diversity in north-west Mediterranean coastal waters: assessment through clone libraries, fingerprinting and FISH. FEMS Microbiol Ecol 60: 98-112.

33. Mary I, Cummings DG, Biegala IC, Burkill PH, Archer SD, et al. (2006) Seasonal dynamics of bacterioplankton community structure at a coastal station in the western English Channel Aqua Microbial Ecol 42: 119-126.

34. Campbell BJ, Yu L, Heidelberg JF, Kirchman DL (2011) Activity of abundant and rare bacteria in a coastal ocean. Proc Natl Acad Sci USA 108: 12776-12781.

35. Hugoni M, Taib N, Debroas D, Domaizon I, Jouan Dufournel I, et al. (2013) Structure of the rare archaeal biosphere and seasonal dynamics of active ecotypes in surface coastal waters. Proc Natl Acad Sci USA 110: 6004-6009.

36. Lorenzen CJ (1967) Determination of chlorophyll and pheopigments: spectrophotometric equations. Limnol Oceanogr 12: 343-346.

37. Strickland J, Parsons T (1968) A practical handbook of sea water analysis.

38. Takai K, Horikoshi K (2000) Rapid detection and quantification of members of the archaeal community by quantitative PCR using fluorogenic probes. Appl Environ Microbiol 66: 5066-5072.

39. Kim M, Morrison M, Yu Z (2011) Evaluation of different partial 16S rRNA gene sequence regions for phylogenetic analysis of microbiomes. J Microbiol Methods 84: $490 \quad 81-87$.

40. Taib N, Mangot JF, Domaizon I, Bronner G, Debroas D (2013) Phylogenetic affiliation of SSU rRNA genes generated by massively parallel sequencing: new insights into the freshwater protist diversity. PLoS One 8: e58950.

41. Edgar RC, Haas BJ, Clemente JC, Quince C, Knight R (2011) UCHIME improves sensitivity and speed of chimera detection. Bioinformatics 27: 2194-2200. 
42. Edgar RC (2004) MUSCLE: multiple sequence alignment with high accuracy and high throughput. Nucleic Acids Res 32: 1792-1797.

43. Tamura K, Peterson D, Peterson N, Stecher G, Nei M, et al. (2011) MEGA5: molecular evolutionary genetics analysis using maximum likelihood, evolutionary distance, and maximum parsimony methods. Mol Biol Evol 28: 2731-2739.

44. Francis CA, Roberts KJ, Beman JM, Santoro AE, Oakley BB (2005) Ubiquity and diversity of ammonia-oxidizing archaea in water columns and sediments of the ocean. Proc Natl Acad Sci USA 102: 14683-14688.

45. Borcard D, Legendre P, Drapeau P (1992) Partialling out the spatial component of ecological variation. Ecology 73: 1045-1055.

46. Massana R, DeLong EF, Pedros-Alio C (2000) A few cosmopolitan phylotypes dominate planktonic archaeal assemblages in widely different oceanic provinces. Appl Environ Microbiol 66: 1777-1787.

47. Abell GC, Revill AT, Smith C, Bissett AP, Volkman JK, et al. (2010) Archaeal ammonia oxidizers and nirS-type denitrifiers dominate sediment nitrifying and denitrifying populations in a subtropical macrotidal estuary. ISME J 4: 286-300.

48. Martens-Habbena W, Berube PM, Urakawa H, de la Torre JR, Stahl DA (2009) Ammonia oxidation kinetics determine niche separation of nitrifying Archaea and Bacteria. Nature 461: 976-979.

49. Winter C, Bouvier T, Weinbauer MG, Thingstad TF (2010) Trade-offs between competition and defense specialists among unicellular planktonic organisms: the "killing the winner" hypothesis revisited. Microbiol Mol Biol Rev 74: 42-57.

50. Sintes E, Bergauer K, De Corte D, Yokokawa T, Herndl GJ (2013) Archaeal amoA gene diversity points to distinct biogeography of ammonia-oxidizing Crenarchaeota in the ocean. Environ Microbiol 15: 1647-1658.

51. Auguet JC, Casamayor EO (2013) Partitioning of Thaumarchaeota populations along environmental gradients in high mountain lakes. FEMS Microbiol Ecol 84: 154-164.

52. Restrepo-Ortiz CX, Auguet JC, Casamayor EO (2013) Targeting spatiotemporal dynamics of planktonic SAGMGC-1 and segregation of ammonia-oxidizing thaumarchaeota ecotypes by newly designed primers and quantitative polymerase chain reaction. Environ Microbiol 16: 689-700.

53. Mußmann M, Brito I, Pitcher A, Sinninghe Damste JS, Hatzenpichler R, et al. (2011) Thaumarchaeotes abundant in refinery nitrifying sludges express amoA but are not obligate autotrophic ammonia oxidizers. Proc Natl Acad Sci USA 108: 16771-16776.

530 54. Pester M, Rattei T, Flechl S, Grongroft A, Richter A, et al. (2011) amoA-based consensus phylogeny of ammonia-oxidizing archaea and deep sequencing of amoA genes from soils of four different geographic regions. Environ Microbiol 14: 525-539.

55. Pulliam HR (1988) Sources, sinks, and population regulation. The American Naturalist 132: 652-661.

56. Barberan A, Fernandez-Guerra A, Auguet JC, Galand PE, Casamayor EO (2011) Phylogenetic ecology of widespread uncultured clades of the Kingdom Euryarchaeota. Mol Ecol 20: 1988-1996.

57. Frigaard NU, Martinez A, Mincer TJ, DeLong EF (2006) Proteorhodopsin lateral gene transfer between marine planktonic Bacteria and Archaea. Nature 439: 847-850.

540 58. Iverson V, Morris RM, Frazar CD, Berthiaume CT, Morales RL, et al. (2012) Untangling genomes from metagenomes: revealing an uncultured class of marine Euryarchaeota. Science 335: 587-590.

59. Meng J, Xu J, Qin D, He Y, Xiao X, et al. (2014) Genetic and functional properties of uncultivated MCG archaea assessed by metagenome and gene expression analyses. ISME J 8: 650-659. 
60. Webster G, O'Sullivan LA, Meng Y, Williams AS, Sass AM, et al. (2015) Archaeal community diversity and abundance changes along a natural salinity gradient in estuarine sediments. FEMS Microbiol Ecol 91: 1-18.

61. Inagaki F, Nunoura T, Nakagawa S, Teske A, Lever M, et al. (2006) Biogeographical distribution and diversity of microbes in methane hydrate-bearing deep marine sediments on the Pacific Ocean Margin. Proc Natl Acad Sci USA 103: 2815-2820.

62. Singh SK, Verma P, Ramaiah N, Chandrashekar AA, Shouche YS (2010) Phylogenetic diversity of archaeal 16S rRNA and ammonia monooxygenase genes from tropical estuarine sediments on the central west coast of India. Res Microbiol 161: 177-186.

555 63. Lloyd KG, Schreiber L, Petersen DG, Kjeldsen KU, Lever MA, et al. (2013) Predominant archaea in marine sediments degrade detrital proteins. Nature 496: 215-218. 


\section{Figures and tables legend}

Figure 1. Location of sampling stations (median position over 12 sampling dates) along the Charente Estuary. The freshwater station was called A, the mesohaline station: C, and the marine station: E.

Figure 2. Abundances of thaumarchaeal (A) and bacterial (B) $a m o A$ transcripts and (C) thaumarchaeal ureC transcripts per $\mathrm{mL}$ of water during the one year survey.

Figure 3. Proportion of $16 \mathrm{~S}$ rRNA genes transcripts for archaeal groups retrieved in the freshwater station, the mesohaline station, and the marine station during three distinct periods: from April to August, from September to November and from December to March.

Figure 4. 16S rRNA transcripts phylogenetic tree including potentially active Thaumarchaeota MGI OTUs retrieved in the three sampling stations of the Charente estuary. Bootstrap values $>40$ are shown. Histograms on the right represented the number of OTUs retrieved in each station, in the freshwater and mesohaline stations, in the mesohaline and marine stations and in the 3 stations. Seasonal changes in Thaumarchaeota OTUs from the Marine A cluster were illustrated for OTUs in the mesohaline station which were active from

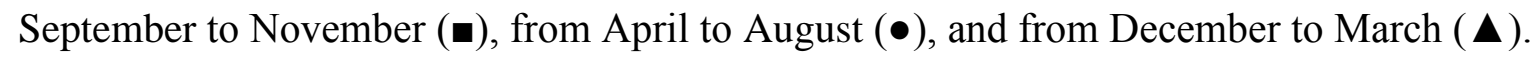

Figure 5. RDA plot of $u r e C$ and $a m o A$ transcripts abundance ( $\square$ ) compared with active abundant Thaumarchaeota MGI OTUs ( $\boldsymbol{\Delta}$ ) according to the stations sampling points $(\bullet)$. The correspondant abbreviated names for OTUs were as follows: R24_HUJ (R24_HUJB0N002JCR91), R10_HUJ (R10_HUJB0N002JLORV), R16_HUJ 580

$\begin{array}{lccc}\text { (R16_HUJB0N002GU20W), } & \text { R34_HUJ } & \text { (R34_HUJB0N002JELSP), } & \text { R8_HTR } \\ \text { (R8_HTRM39R02IN9W4), } & \text { R16_HUJ } & \text { (R16_HUJB0N002ITPEH), } & \text { R17_HTR } \\ \text { (R17_HTRM39R02HMXG2), } & \text { R22_HTR } & \text { (R22_HTRM39R02HVYCX), } & \text { D32_HUJ } \\ \text { (D32_HUJB0N002F6TFA), R22_HTR (R22_HTRM39R02GQZTZ). } & \end{array}$


Table 1. Primers used for qPCR and pyrosequencing, and PCR annealing conditions used in 585 this study. 


\section{Supplementary Data}

Supplementary Figure 1. Box plot of Shannon index from the three different sampling 590 stations. A significant difference in diversity between two stations is marked with a star $(*, p$ $<0.008)$.

Supplementary Figure 2. Ordination diagram from CCA of major active archaeal groups compared with environmental data.

Supplementary Table 1. Quality checked (QC) and Archaea affiliated sequences obtained

595 for each sample from surface water collected monthly in the Charente estuary. Environmental parameters (temperature, salinity, $\mathrm{pH}$ and $\mathrm{Chl} a$, ammonia and phosphates concentrations) associated to each point are presented. ND: not determined.

Supplementary Table 2. Mean number of 16S rRNA sequences associated with each abundant OTU retrieved in the freshwater, mesohaline and marine stations. ND: not 600 determined.

Supplementary Table 3. Monthly community structure at the subcluster level in Thaumarchaeota MGI. Number of OTUs were presented for each subgroup and number of sequences between brackets. ND: not determined. 


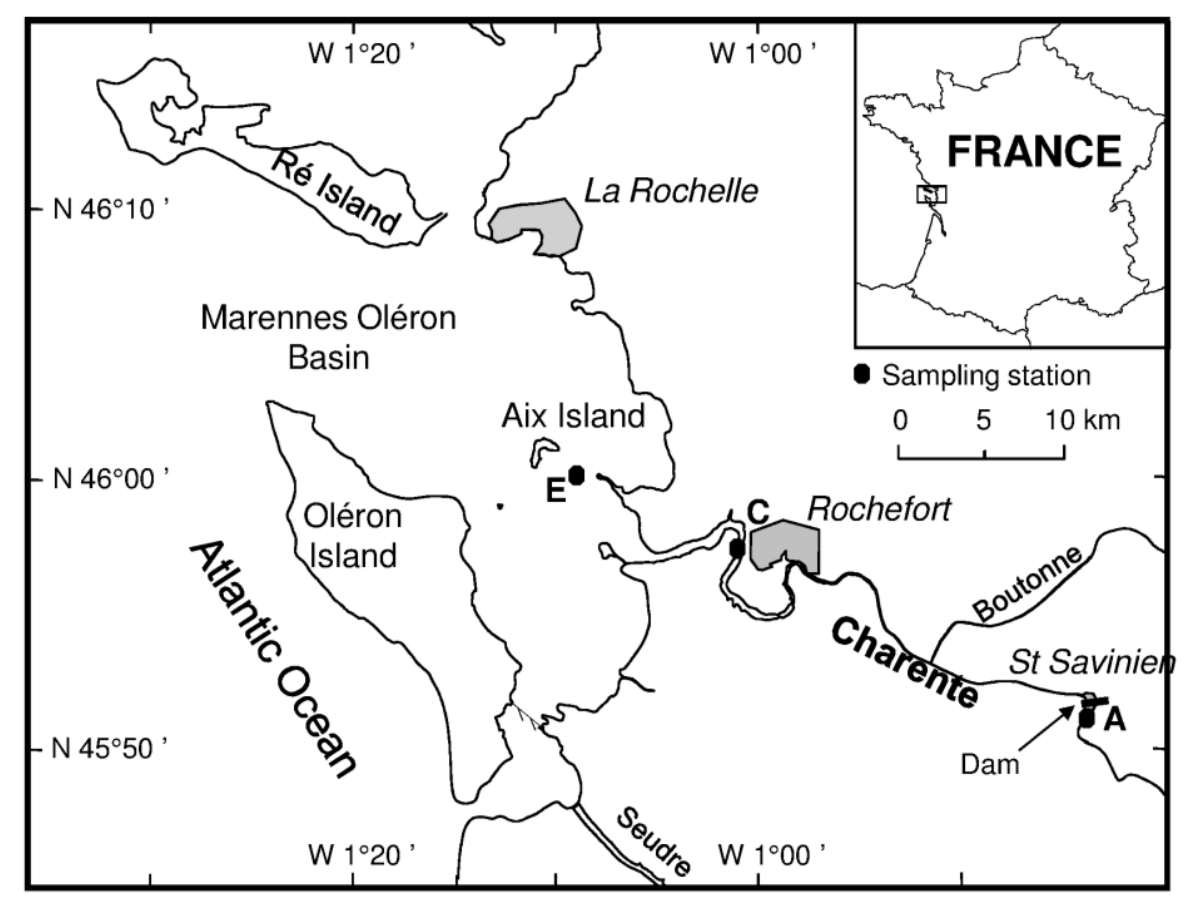

610

Figure 1. Hugoni et al.

615

620

625 
640
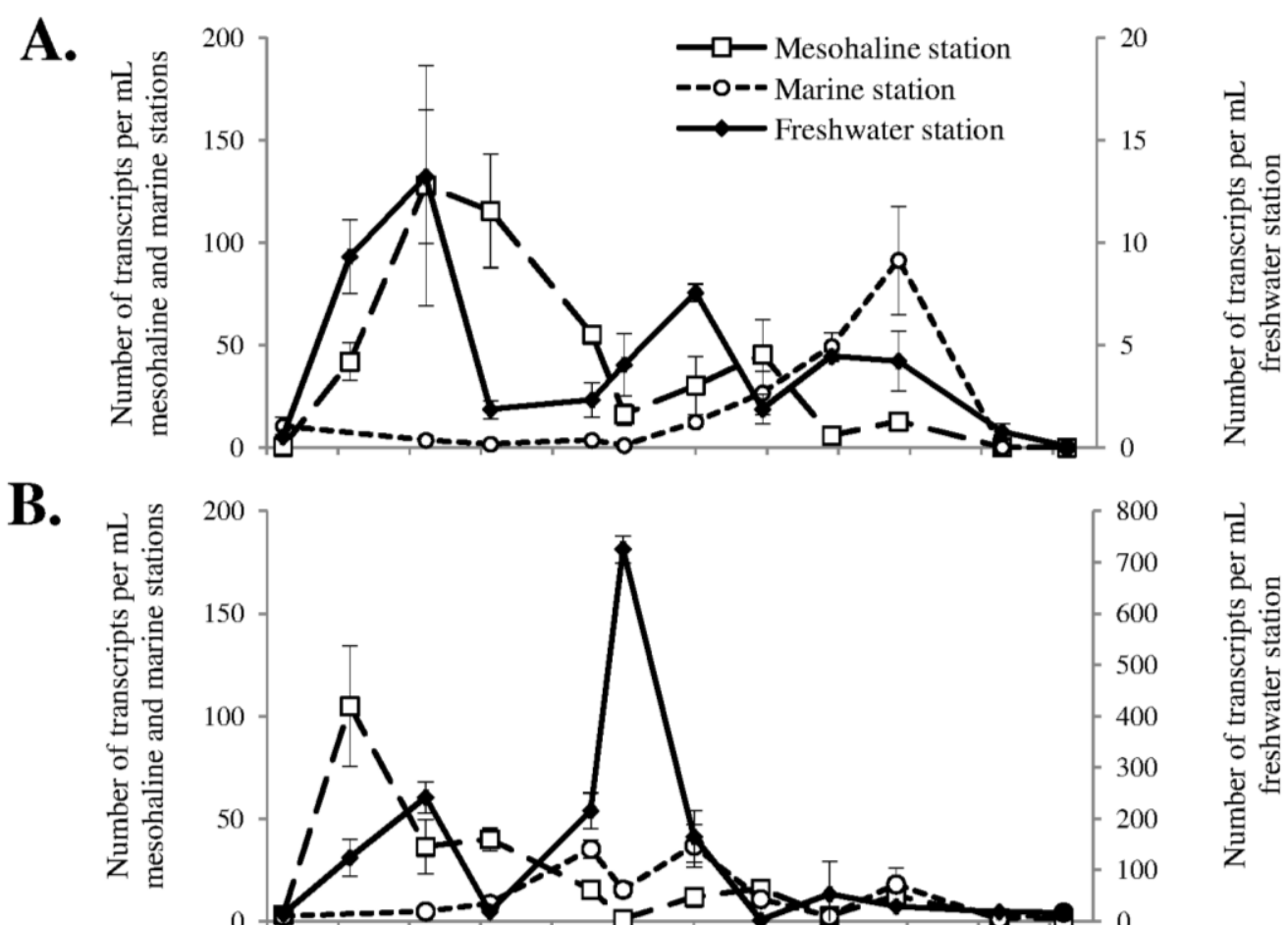

C.

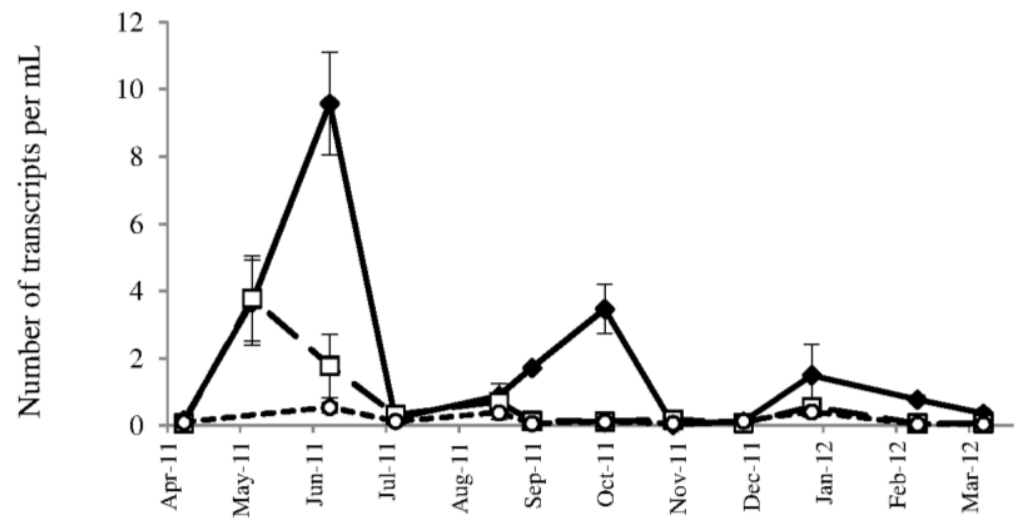

Figure 2. Hugoni et al. 


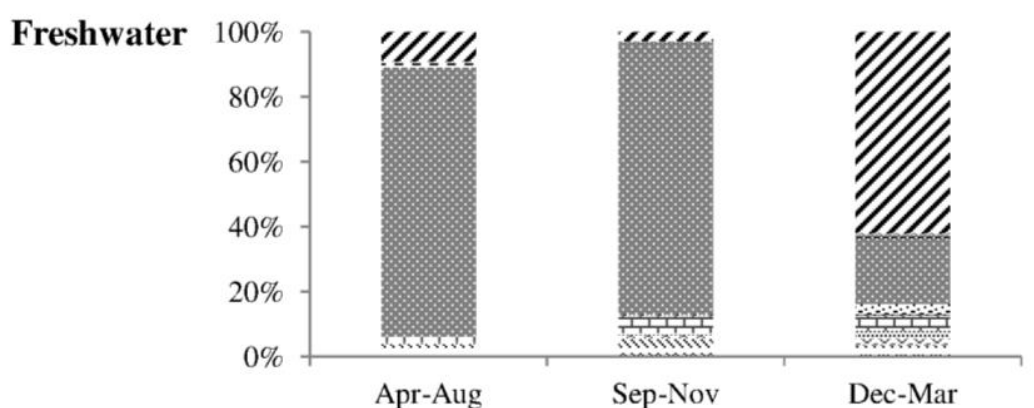

Mesohaline

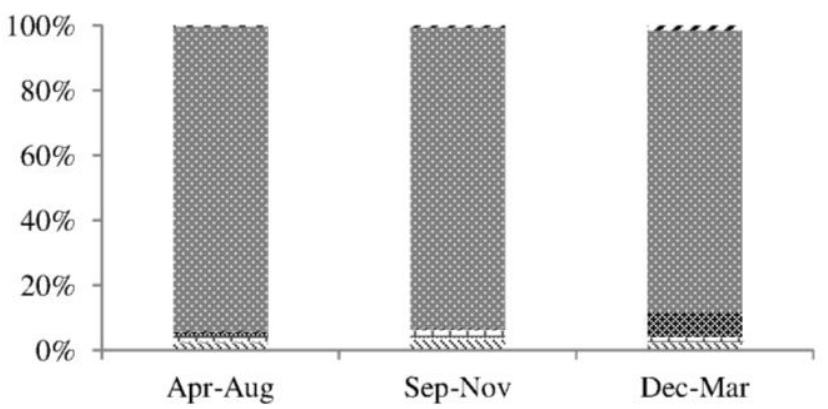

Marine

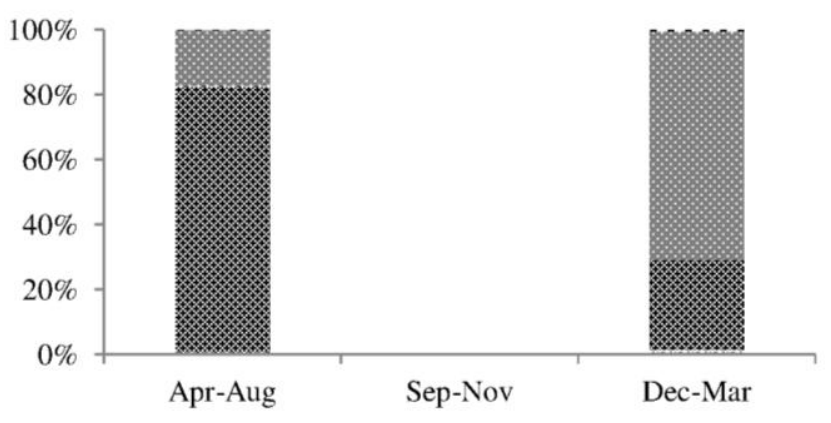

\% Methanogenic lineages

*Archaea_AAG

a Cren_AK8

-- Eury_AMOS1A-4113-D04

Eury_WCHA2-08

*Thaum_SCG

睡 Eury_SM1K20

: Thaum_SAGMCG-1

\& Thaum_MGI

Eury_CA11

: Eury_TMEG

* Eury_MGII

$\because$ Eury_MBGD/DHVEG-1

a Eury_CCA47

古Eury_RC-V

IIII Eury_GOMArcI

t Eury_LDS

谷Eury_MEG

s Eury_MHVG

"Eury_DHVEG-6

Eury_DSEG

i:Cren_MCG

Figure 3. Hugoni et al.

665

670 


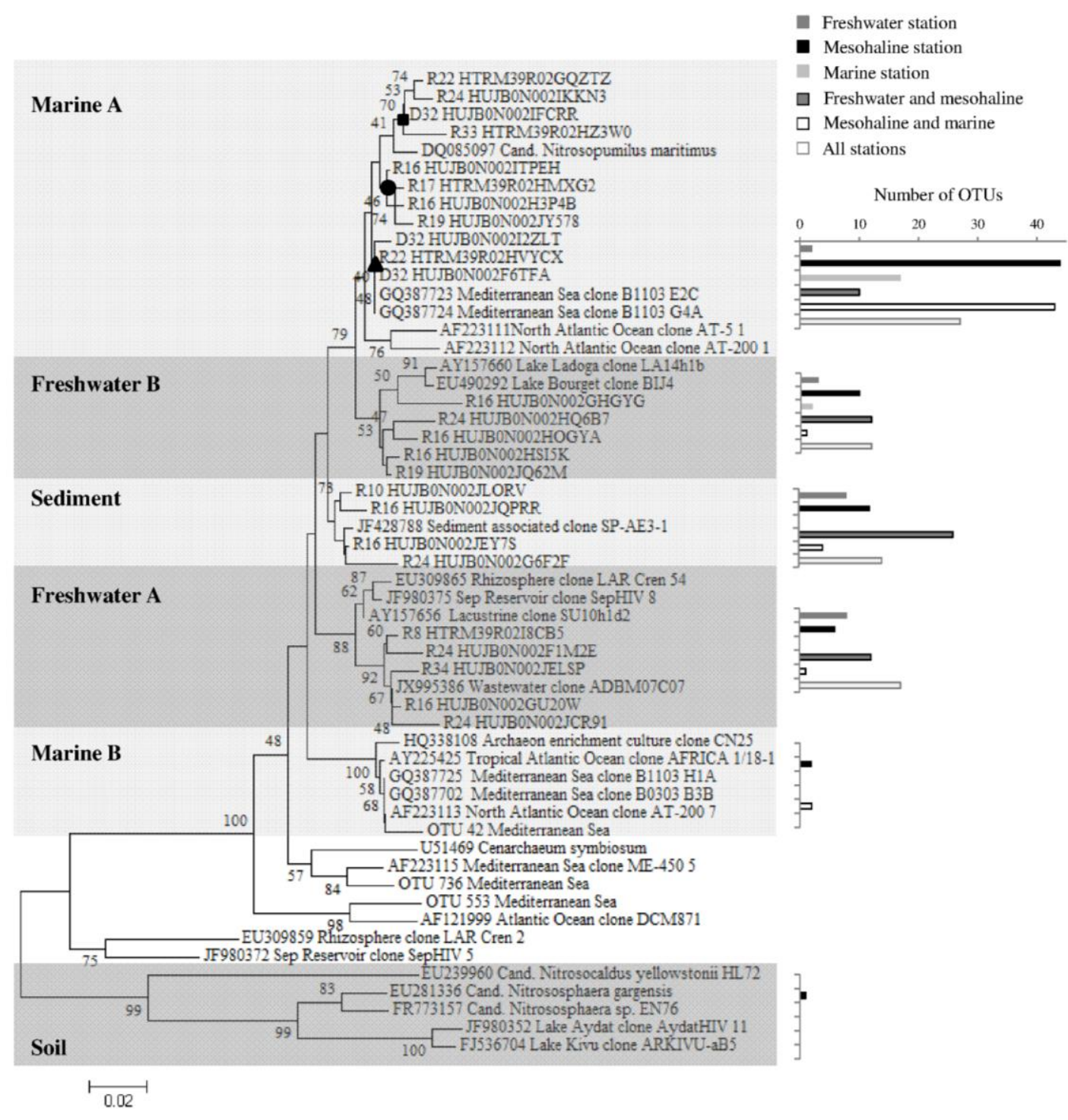

685

Figure 4. Hugoni et al.

690 


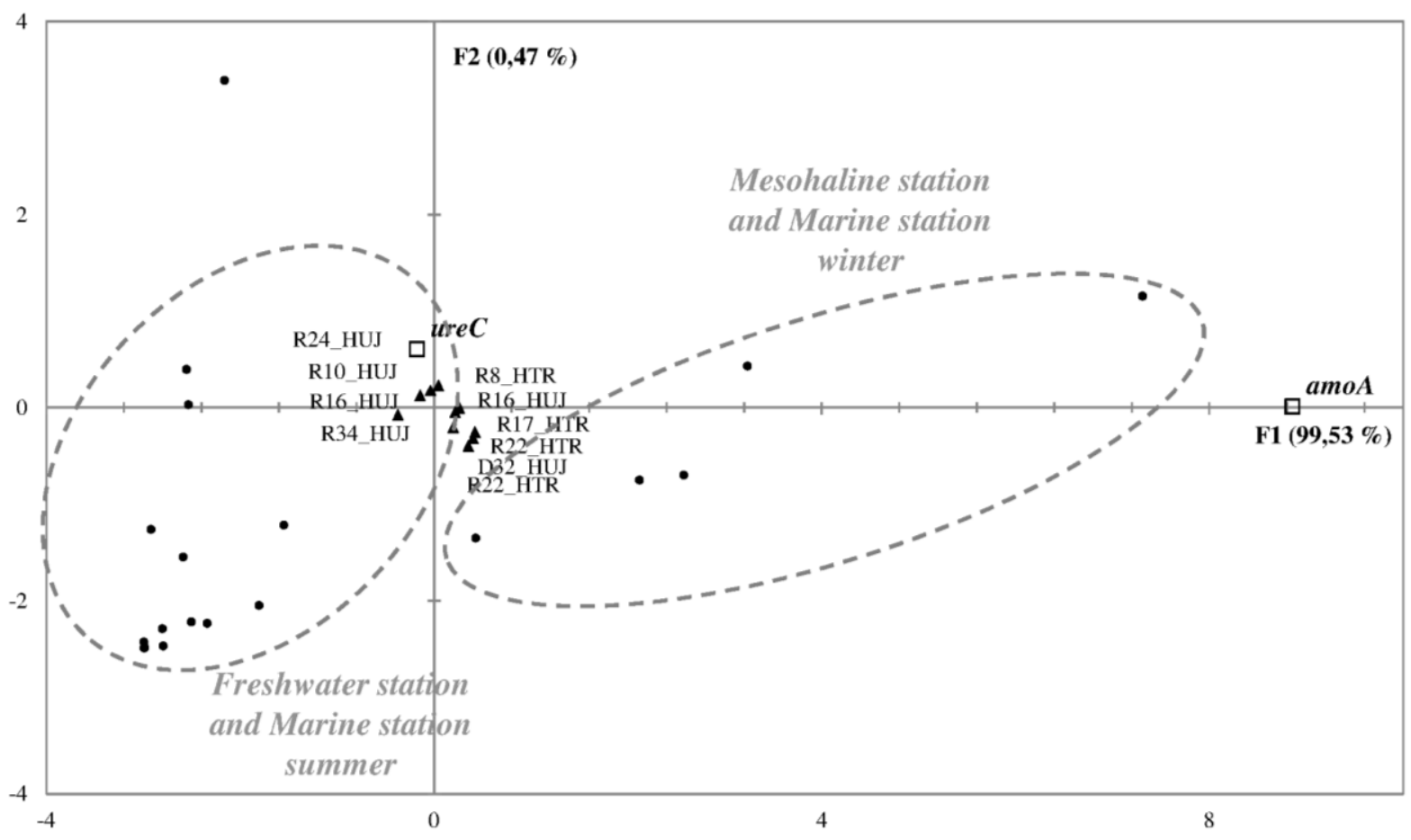

705

Figure 5. Hugoni et al. 


\begin{tabular}{|c|c|c|c|c|c|}
\hline Application & Primer & Primer sequence $5^{\prime}-3^{\prime}$ & $\begin{array}{l}\text { Annealing } \\
\text { temperature }\end{array}$ & Targeted group & Reference \\
\hline \multirow[t]{6}{*}{ qPCR } & amoA-1F & GGGGTTTCTACTGGTGGT & \multirow{2}{*}{$56^{\circ} \mathrm{C}$} & \multirow{2}{*}{$\beta$-proteobacterial amoA } & \multirow{2}{*}{$\begin{array}{l}\text { Rotthauwe et } \\
\text { al., } 1997\end{array}$} \\
\hline & AmoA-RNEW & СCCCTCBGSAAAVCCTTCTTC & & & \\
\hline & CrenAmoAModF & TGGCTAAGACGMTGTA & \multirow{2}{*}{$52^{\circ} \mathrm{C}$} & \multirow{2}{*}{ Thaumarchaeal amoA } & \multirow{2}{*}{ Mincer et al., 2007} \\
\hline & CrenAmoAModR & AAGCGGCCATCCATCTGTA & & & \\
\hline & Thaum-UreC F & ATGCAATYTGTAATGGAACWACWAC & \multirow{2}{*}{$55^{\circ} \mathrm{C}$} & \multirow{2}{*}{ Thaumarchaeal ureC } & \multirow{2}{*}{$\begin{array}{c}\text { Alonso-Saez et al., } \\
2012\end{array}$} \\
\hline & Thaum-UreC R & AGTTGTYCCCCAATCTTCATGTAATTTTA & & & \\
\hline \multirow[t]{6}{*}{ Pyrosequencing } & Arch349F & GYGCASCAGKCGMGAAW & \multirow{2}{*}{$55^{\circ} \mathrm{C}$} & \multirow{2}{*}{ Archaeal 16S rRNA } & \multirow{2}{*}{ Takai et al., 2000} \\
\hline & Arch 806R & GGACTACVSGGGTATCTAAT & & & \\
\hline & amoA-1F & GGGGTTTCTACTGGTGGT & \multirow{2}{*}{$56^{\circ} \mathrm{C}$} & \multirow{2}{*}{$\beta$-proteobacterial amoA } & \multirow{2}{*}{$\begin{array}{l}\text { Rotthauwe et } \\
\text { al.,1997 }\end{array}$} \\
\hline & Bacamo2R & CCCCTCKGSAAAGCCTTCTTC & & & \\
\hline & Arch-amoAF & STAATGGTCTGGCTTAGACG & \multirow{2}{*}{$53^{\circ} \mathrm{C}$} & \multirow{2}{*}{ Thaumarchaeal amoA } & \multirow{2}{*}{ Francis et al.,2005 } \\
\hline & Arch-amoAR & GCGGCCATCCATCTGTATGT & & & \\
\hline
\end{tabular}

Table 1. Hugoni et al.

740

745 


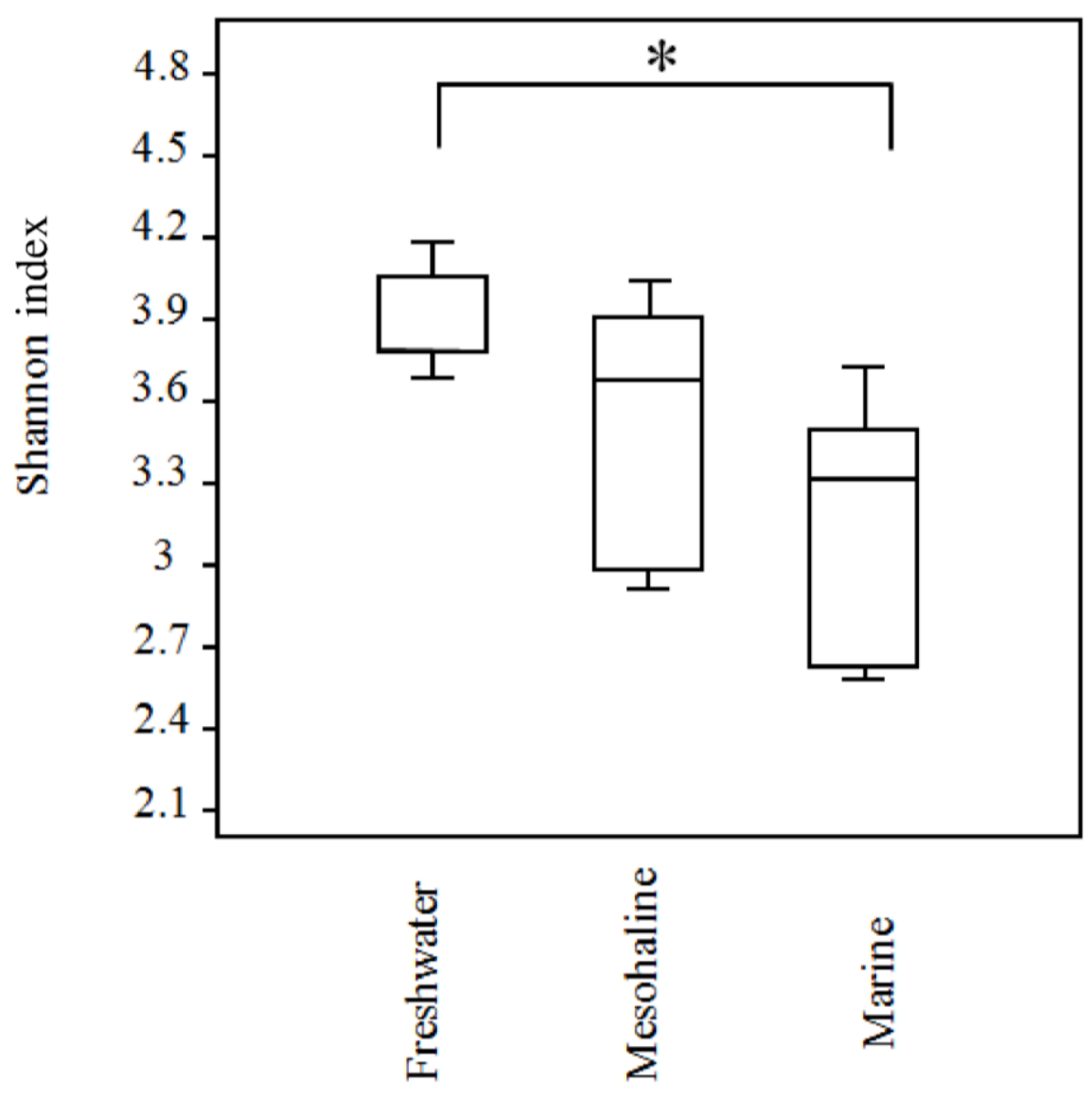

Supplementary Figure 1. Hugoni et al.

760

765

770

775 


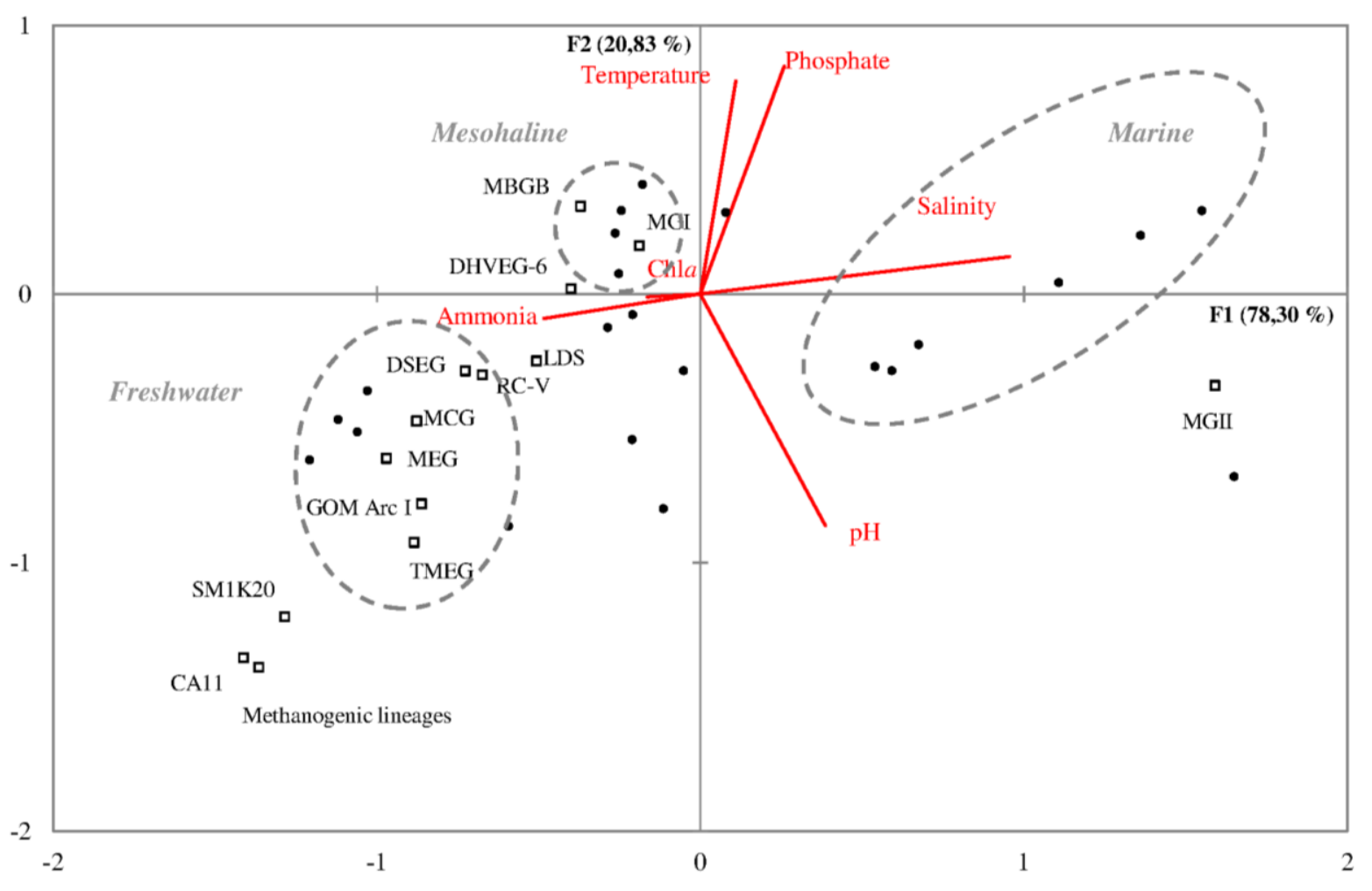

Supplementary Figure 2. Hugoni et al. 


\begin{tabular}{|c|c|c|c|c|c|c|c|c|c|c|}
\hline & \multirow[t]{2}{*}{ Date } & QC seq. & $\begin{array}{c}\text { Archaea } \\
\text { affiliated } \\
\text { sequences }\end{array}$ & $\begin{array}{c}\text { Thaumarchaeota } \\
\text { affiliated } \\
\text { sequences }\end{array}$ & \multirow[t]{2}{*}{$\begin{array}{l}\text { Temp. } \\
\left({ }^{\circ} \mathrm{C}\right)\end{array}$} & \multirow[t]{2}{*}{$\begin{array}{l}\text { Sal. } \\
\text { (PSU) }\end{array}$} & \multirow[t]{2}{*}{$\mathrm{pH}$} & \multirow[t]{2}{*}{$\begin{array}{c}\text { Chla } \\
\left(\mu g \cdot L^{-1}\right)\end{array}$} & \multirow[t]{2}{*}{$\underset{\left(m g \cdot L^{-1}\right)}{\mathrm{NH}_{4}{ }^{+}}$} & \multirow[t]{2}{*}{$\begin{array}{c}\mathrm{PO}_{4}{ }^{3-} \\
\left(\mathrm{mg}^{-\mathrm{L}^{-1}}\right)\end{array}$} \\
\hline & & \multicolumn{3}{|c|}{ 16SrRNA } & & & & & & \\
\hline \multirow{12}{*}{ Freshwater } & $14 / 04 / 2011$ & ND & ND & ND & 16.9 & 0 & 8.65 & 3.618 & 0.113 & 0.008 \\
\hline & $13 / 05 / 2011$ & ND & ND & ND & 20.7 & 0 & 8.39 & 6.686 & 0.030 & 0.018 \\
\hline & $15 / 06 / 2011$ & 2966 & 177 & 147 & 21.7 & 0 & 8.28 & 28.48 & 0.081 & 0.008 \\
\hline & $13 / 07 / 2011$ & 4163 & 52 & 0 & 23.7 & 0 & 8.04 & 5.658 & 0.143 & 0.082 \\
\hline & $26 / 08 / 2011$ & 1613 & 20 & 0 & 23.5 & 0 & 8.18 & 63.665 & 0.036 & 0.111 \\
\hline & $09 / 09 / 2011$ & 3351 & 116 & 90 & 21.7 & 0 & 8.13 & 56.069 & 0.049 & 0.021 \\
\hline & $10 / 10 / 2011$ & 2057 & 212 & 158 & 18.3 & 0 & 8.22 & 33.94 & 0.065 & 0.056 \\
\hline & $08 / 11 / 2011$ & 3055 & 1616 & 1375 & 13.8 & 0 & 8.14 & 2.031 & 0.078 & 0.034 \\
\hline & $08 / 12 / 2011$ & 4909 & 394 & 229 & 11.5 & 0 & 8.21 & 0.691 & 0.122 & 0.014 \\
\hline & $06 / 01 / 2012$ & 5171 & 592 & 118 & 10.5 & 0 & 8.14 & 1.57 & 0.068 & 0.024 \\
\hline & $20 / 02 / 2012$ & 4501 & 946 & 41 & 7.2 & 0 & 8.1 & 7.089 & 0.081 & 0.011 \\
\hline & $19 / 03 / 2012$ & 306 & 35 & 0 & 12.1 & 0 & ND & 1.751 & 0.108 & 0.069 \\
\hline \multirow{12}{*}{ Mesohaline } & $14 / 04 / 2011$ & ND & ND & ND & 15.4 & 14.3 & 8.48 & 5.264 & 0.0 & 0.011 \\
\hline & $13 / 05 / 2011$ & ND & ND & ND & 19.4 & 14.7 & 8.5 & 3.296 & 0.011 & 0.011 \\
\hline & $15 / 06 / 2011$ & 734 & 356 & 318 & 21 & 14.5 & 7.91 & 3.873 & 0.317 & 0.043 \\
\hline & $13 / 07 / 2011$ & 16263 & 7229 & 6833 & 22.1 & 15.4 & 7.78 & 5.054 & 0.043 & 0.114 \\
\hline & $26 / 08 / 2011$ & 1610 & 797 & 699 & 22.8 & 14.7 & 7.89 & 9.805 & 0.064 & 0.079 \\
\hline & $09 / 09 / 2011$ & ND & ND & ND & 21.1 & 14.3 & 7.58 & 4.276 & 0.0 & 0.069 \\
\hline & $10 / 10 / 2011$ & 4136 & 2798 & 2607 & 18 & 14.7 & 7.79 & 4.669 & 0.032 & 0.085 \\
\hline & $08 / 11 / 2011$ & 1169 & 724 & 645 & 13.7 & 14.3 & 7.9 & 2.736 & 0.033 & 0.056 \\
\hline & $08 / 12 / 2011$ & 1198 & 808 & 759 & 11.9 & 14.6 & 7.98 & 1.383 & 0.0 & 0.056 \\
\hline & $06 / 01 / 2012$ & 5042 & 3418 & 3041 & 10.2 & 15.7 & 8.12 & 0.661 & 0.05 & 0.03 \\
\hline & $20 / 02 / 2012$ & ND & ND & ND & 5.9 & 14.7 & 7.91 & 1.895 & 0.058 & 0.03 \\
\hline & $19 / 03 / 2012$ & 4784 & 1878 & 1478 & 10.4 & 15.2 & 7.87 & 9.28 & 0.020 & 0.056 \\
\hline \multirow{11}{*}{ Marine } & $14 / 04 / 2011$ & 2313 & 1688 & 415 & 13.7 & 33.2 & 8.58 & 0.898 & 0.0 & 0.056 \\
\hline & $15 / 06 / 2011$ & 3298 & 1632 & 166 & 18.7 & 34.3 & 8.03 & 2.908 & 0.0 & 0.091 \\
\hline & $13 / 07 / 2011$ & 1909 & 586 & 97 & 21 & 35 & 8.03 & 5.078 & 0.0 & 0.088 \\
\hline & $26 / 08 / 2011$ & ND & ND & $\mathrm{ND}$ & 21.8 & 34.2 & 8.23 & 4.48 & 0.0 & 0.095 \\
\hline & $09 / 09 / 2011$ & ND & ND & ND & 20.7 & 35 & 8.07 & 1.946 & 0.0 & 0.062 \\
\hline & $10 / 10 / 2011$ & ND & ND & ND & 18.3 & 35.3 & 7.99 & 2.912 & 0.0 & 0.072 \\
\hline & $08 / 11 / 2011$ & ND & ND & ND & 14.5 & 34.8 & 8.03 & 1.312 & 0.0 & 0.261 \\
\hline & $08 / 12 / 2011$ & 429 & 337 & 310 & 12.6 & 33.6 & 8.02 & 0.803 & 0.0 & 0.072 \\
\hline & $06 / 01 / 2012$ & 1059 & 708 & 646 & 10.5 & 28.3 & 8.1 & 0.939 & 0.0599 & 0.075 \\
\hline & $20 / 02 / 2012$ & 914 & 334 & 219 & 6 & 32.8 & 7.95 & 1.419 & 0.071 & 0.082 \\
\hline & $19 / 03 / 2012$ & 1179 & 350 & 43 & 9.5 & 33.7 & 7.9 & 7.5 & 0.082 & 0.098 \\
\hline
\end{tabular}


Average number of sequences

\begin{tabular}{|c|c|c|c|c|c|}
\hline Station & MGI Subluster & Representative OTU & Apr-Aug & Sep-Nov & Dec-Mar \\
\hline \multirow{11}{*}{$\begin{array}{l}\text { Freshwater } \\
\text { station }\end{array}$} & Marine A & D32_HUJB0N002IFCRR & 0 & 14 & 0 \\
\hline & \multirow{4}{*}{ Freshwater A } & R34_HUJB0N002JELSP & 17 & 60 & 24 \\
\hline & & R16_HUJB0N002GU20W & 16 & 43 & 10 \\
\hline & & R24_HUJB0N002JCR91 & 5 & 39 & 8 \\
\hline & & R8_HTRM39R02I8CB5 & 1 & 20 & 1 \\
\hline & \multirow{3}{*}{ Freshwater B } & R24_HUJB0N002HQ6B7 & 10 & 20 & 3 \\
\hline & & R16_HUJB0N002HSI5K & 7 & 20 & 3 \\
\hline & & R8_HTRM39R02IN9W4 & 0 & 15 & 2 \\
\hline & \multirow{3}{*}{ Sediment } & R16_HUJB0N002JEY7S & 19 & 44 & 9 \\
\hline & & R10_HUJB0N002JLORV & 6 & 20 & 5 \\
\hline & & R7_HTRM39R02F36EW & 5 & 20 & 3 \\
\hline \multirow{17}{*}{$\begin{array}{l}\text { Mesohaline } \\
\text { station }\end{array}$} & \multirow{3}{*}{ Marine A.c } & R22_HTRM39R02HVYCX & 49 & 66 & 398 \\
\hline & & D32_HUJB0N002F6TFA & 5 & 19 & 303 \\
\hline & & D32_HUJB0N002I2ZLT & 1 & 6 & 84 \\
\hline & \multirow{5}{*}{ Marine A.b } & R16_HUJB0N002H3P4B & 323 & 101 & 47 \\
\hline & & R19_HUJB0N002JY578 & 52 & 18 & 9 \\
\hline & & R17_HTRM39R02HMXG2 & 59 & 16 & 3 \\
\hline & & R16_HUJB0N002ITPEH & 175 & 73 & 24 \\
\hline & & R16_HUJB0N002ICU9P & 87 & 34 & 8 \\
\hline & \multirow{2}{*}{ Marine A.a } & D32_HUJB0N002IFCRR & 129 & 131 & 105 \\
\hline & & R17_HTRM39R02HNRQI & 26 & 115 & 3 \\
\hline & \multirow{2}{*}{ Sediment } & R16_HUJB0N002JEY7S & 181 & 71 & 31 \\
\hline & & R10_HUJB0N002JLORV & 48 & 17 & 11 \\
\hline & \multirow{3}{*}{ Freshwater A } & R24_HUJB0N002JCR91 & 48 & 24 & 18 \\
\hline & & R16_HUJB0N002GU20W & 115 & 43 & 50 \\
\hline & & R34_HUJB0N002JELSP & 199 & 84 & 78 \\
\hline & \multirow{2}{*}{ Freshwater B } & R24_HUJB0N002HQ6B7 & 81 & 38 & 47 \\
\hline & & R16_HUJB0N002HSI5K & 47 & 19 & 29 \\
\hline \multirow{6}{*}{ Marine station } & \multirow{6}{*}{ Marine A } & D32_HUJB0N002F6TFA & 34 & ND & 88 \\
\hline & & R22_HTRM39R02HVYCX & 47 & ND & 75 \\
\hline & & D32_HUJB0N002I2ZLT & 12 & ND & 18 \\
\hline & & D32_HUJB0N002IFCRR & 26 & ND & 12 \\
\hline & & R16_HUJB0N002H3P4B & 12 & ND & 7 \\
\hline & & R25_HTRM39R02GJ5BA & 10 & ND & 8 \\
\hline
\end{tabular}

Supplementary Table 2. Hugoni et al.

835 


\begin{tabular}{|c|c|c|c|c|c|c|c|c|c|c|c|}
\hline M GI Subluster & 14-Apr & 15-Jun & 13-Jul & 26-Aug & 9-Sep & 10-Oct & 8-Nov & 8-Dec & 6-Jan & 20-Feb & 19-Mar \\
\hline Marine A & ND & 0 & ND & ND & 0 & $1(1)$ & $1(42)$ & $1(1)$ & 0 & 0 & ND \\
\hline Freshwater A & ND & $4(39)$ & ND & ND & $4(21)$ & $4(57)$ & $4(405)$ & $4(75)$ & $4(37)$ & $3(17)$ & $\mathrm{ND}$ \\
\hline Freshwater B & ND & $3(17)$ & ND & ND & $2(15)$ & $2(9)$ & $3(140)$ & $3(16)$ & $3(8)$ & 0 & ND \\
\hline Sediment & ND & $3(30)$ & ND & ND & $3(15)$ & $3(29)$ & $3(209)$ & $3(28)$ & $3(18)$ & $2(4)$ & ND \\
\hline Marine A & ND & $8(140)$ & $10(2243)$ & $10(334)$ & ND & $10(894)$ & $10(258)$ & $10(516)$ & 10 (2166) & ND & $8(269)$ \\
\hline Freshwater A & ND & $3(35)$ & $3(977)$ & $3(75)$ & ND & $3(225)$ & $3(74)$ & $3(24)$ & $3(64)$ & ND & $3(349)$ \\
\hline Freshwater B & ND & $2(22)$ & $2(322)$ & $2(40)$ & ND & $2(95)$ & $2(18)$ & $2(3)$ & $2(8)$ & ND & $2(217)$ \\
\hline Sediment & $\mathrm{ND}$ & $2(25)$ & $2(630)$ & $2(33)$ & ND & $2(135)$ & $2(39)$ & $2(19)$ & $2(37)$ & ND & $2(70)$ \\
\hline MarineA & $6(307)$ & $6(78)$ & $\mathrm{ND}$ & ND & ND & $\mathrm{ND}$ & ND & $6(221)$ & $6(480)$ & $6(116)$ & $1(12)$ \\
\hline Freshwater A & 0 & 0 & ND & ND & ND & ND & ND & 0 & 0 & 0 & 0 \\
\hline Freshwater B & 0 & 0 & ND & $\mathrm{ND}$ & $\mathrm{ND}$ & ND & $\mathrm{ND}$ & 0 & 0 & 0 & 0 \\
\hline Sediment & 0 & 0 & ND & ND & ND & ND & ND & 0 & 0 & 0 & 0 \\
\hline
\end{tabular}

